\title{
The Coyote Is Not Inside You: Gary Snyder's Ecopoetry ANd Neo-Aristotelian Thought
}

\begin{abstract}
Close-reading selected poems and essays by Gary Snyder, the article examines an apparent epistemological contradiction in Snyder's environmentalist message. As a rule Snyder consistently relies on essentialist discourse, what with his frequent references to human nature, the collective unconscious, mankind's generic identity and man's inner voice. In the poem "The Call of the Wild," however, he questions man's ability to retrieve a "natural" generic core through, say, meditation or vision quests. This apparent contradiction is resolved when one views Snyder's work through the lens of Neo-Aristotelian thought as exemplified by G.E.M. Anscombe's, Martha Nussbaum's, and Terry Eagleton's concepts of human nature. To these philosophers, like to Aristotle, human nature is not a static biological given, but rather a mental predisposition. Thus it is more of a task, or challenge, than a set of characteristics. Making the most of one's humanity is to Neo-Aristotelians comparable to "flourishing" (the metaphor they often use) as a human being. Such ideas resonate with Snyder's concepts of ever-changing human nature and, most importantly, with his conceptual metaphor of the wilderness as Nature's climactic state of being (the "climax" metaphor being clearly comparable to that of "flourishing").
\end{abstract}

\section{Key words}

Gary Snyder; ecopoetry; environmentalism; flourishing; the wilderness; human nature; Neo-Aristotelian philosophy

The British critic Jonathan Bate has rightly described Gary Snyder as "the most ecologically self-conscious of twentieth century poets" (2000: 246). Though not always in the foreground, environmentalism has always been present in Snyder's work $^{1}$. Over the years the prominence of environmentalist thought kept growing 
within the constantly evolving philosophical context of his texts. Ever since the publication of Riprap in 1959, the American poet, essayist, and activist seems to have viewed his diverse literary projects as so many ways of expressing a single concern - that of finding a personal solution to the large-scale spiritual crisis in America, resultant, as he sees it, from Americans' emotional and intellectual separation from their natural environment. Snyder's poems and essays have been thus testimonies to his existential choices in a more direct and emphatic manner than is often the case with contemporary Western writers.

What makes Snyder's ecological argument particularly intriguing is its seemingly self-contradictory philosophical grounding. On the one hand his ontological stance is ostensibly essentialist, what with the frequent references to human nature, the collective unconscious, mankind's generic identity and man's inner voice $^{2}$. On the other - in the poem "The Call of the Wild," to quote but the most famous example, Snyder apparently questions a human being's ability to find within himself/herself the natural, generic wildness that would be commensurate with what the vanishing Californian wilderness (epitomized by the coyote) has to offer. Though otherwise a consistently outspoken advocate of meditation, Snyder seems to argue that without the wilderness out there one cannot find any meaningful and sustainable wildness within. The "natural" mindscape is a hollow, meaningless term without the natural landscape sustaining it. It is this apparent epistemological contradiction - an essentialist speaking in anti-essentialist terms - that I intend to address.

Comparing poetry with expository prose, though admittedly problematic in orthodox literary studies, seems perfectly justified in the case of Snyder, who consistently blends his poetic persona with the "real" Gary Snyder, an American Zen-Buddhist and political activist. The poem "I Went into the Maverick Bar" (first published in 1969) succinctly expresses Snyder's larger socio-political concerns:

I went into the Maverick Bar

In Farmington, New Mexico.

And drank double shots of bourbon

Backed with beer.

My long hair was tucked up under a cap

I'd left the earring in the car.

Two cowboys did horseplay

by the pool tables,

A waitress asked us

where are you from?

a country-and-western band began to play

"We don't smoke Marijuana in Muskokie"

And with the next song,

A couple began to dance. 
They held each other like in High School dances in the fifties;

I recalled when I worked in the woods and the bars of Madras, Oregon.

That short-haired joy and roughness America - your stupidity.

I could almost love you again.

We left - onto the freeway shoulders under the tough old stars -

In the shadow of bluffs I came back to myself,

To the real work, to "What is to be done."

Even if interpreted in isolation from Snyder's essayistic prose, the possible meanings of the "real work" seem fairly clear. The poet's visit in a New Mexico country bar emblematizes an encounter between two hostile cultures, both of them American. In this context the waitress's otherwise perfectly casual question acquires an additional symbolic sense. The poem's speaker is not only a newcomer to Farmington, New Mexico but also, in a way, a stranger in his own country or, more precisely, a stranger to one of the mainstream varieties of his own culture - the traditional, conservative, "redneck" one. The dominant trait of that culture, in Snyder's view, is its intellectual and by the same token spiritual immaturity. Smugly comfortable with their immediate social environment and intellectually infantile, the cowboys and the dancing couple are stuck in a stereotyped version of their own identity. The work "to be done," then, would be some kind of consciousness raising, facilitating the rednecks' spiritual growth and transformation ${ }^{3}$.

The essays included in Earth House Hold provide additional clues as to the character of that work. Here is a pertinent excerpt from "Poetry and the Primitive":

We all live within skin, ego, society, and species boundaries. Consciousness has boundaries of a different order, "the mind is free." College students trying something different because "they do it in New Guinea" is part of the real work of modern man: to uncover the inner structure and actual boundaries of the mind. (1969: 127)

Epistemology is the key to Snyder's socio-political thought. In his view, social liberation must be grounded in mental freedom; personal enlightenment must precede political action. As he puts it in "Buddhism and the Coming Revolution,"

There is nothing in human nature or the requirements of human social organization which intrinsically requires that a culture be contradictory, repressive and productive of violent and frustrated personalities. Recent find- 
ings in anthropology and psychology make this more and more evident. One can prove it for himself by taking a good look at his own nature through meditation. Once a person has this much faith and insight, he must be led to a deep concern with the need for radical social change through a variety of hopefully non-violent means. (1969: 91)

This radical social change denotes any "cultural and economic revolution that moves clearly toward a free, international classless world" (Snyder 1969:92). It also entails "affirming the widest possible spectrum of non-harmful individual behavior - defending the right of individuals to smoke hemp, eat peyote, be polygynous, polyandrous or homosexual. Worlds of behavior and custom long banned by the Judaeo-Capitalist-Christian-Marxist West" (Snyder 1969: 92).

At this point the environmental concerns are not foregrounded, but the essentialist stance on man's generic identity, typical of most environmentalist thinkers, is clearly there. The author of Earth House Hold presupposes the existence of "human nature" whose basic characteristics are accessible through meditation. Apparently expanding on Jung's idea of the collective unconscious, Snyder even goes as far as to suggest that

The traditional cultures are in any case doomed, and rather than cling to their good aspects hopelessly it should be remembered that whatever is or ever was in any other culture can be reconstructed from the unconscious, through meditation. In fact, it is my own view that the coming revolution will close the circle and link us in many ways with the most creative aspects of our archaic past. If we are lucky we may eventually arrive at a totally integrated world culture with matrilineal descent, free-form marriage, naturalcredit communist economy, less industry, far less population and lots more national parks. (1969: 92-93)

This kind of essentialism, to repeat, sounds familiar to most environmentalists. Interestingly enough, though, it seems to contradict what Snyder says in the last strophe of "The Call of the Wild," a long poem from Turtle Island published a decade later. It is the poem, however, not the above-quoted essentialist excerpt from "Buddhism and the Coming Revolution," that stands out in the mass of Snyder's writings.

Before proceeding to the poem, one should perhaps emphasize that "The Call of the Wild" is not the first text, poetic or otherwise, in which Snyder deliberately evades indiscriminate identification with whatever paradigm, creed or ideology he seems to be supporting. For one thing, his outspoken concern with cultural politics goes beyond the traditional limitations of Zen-Buddhist social thought. Earlier in the aforementioned essay Snyder explains:

Historically, Buddhist philosophers have failed to analyze out the degree to which ignorance and suffering are caused and encouraged by social factors, 
considering fear-and-desire to be given facts of the human condition. Consequently the major concern of Buddhist philosophy is epistemology and "psychology" with no attention paid to historical or sociological problems. Although Mahayana Buddhism has a grand vision of universal salvation, the actual achievement of Buddhism has been the development of practical systems of meditation toward the end of liberating a few dedicated individuals from psychological hang-ups and cultural conditionings. Institutional Buddhism has been conspicuously ready to accept or ignore the inequalities and tyrannies of whatever political system it found itself under. This can be death to Buddhism, because it is death to any meaningful function of compassion. Wisdom without compassion feels no pain. (1969: 90)

In this context, "meaningful" can be equated with "social" when it comes to enlightened action resultant from personal spiritual awakening.

Similarly, Snyder goes beyond the traditional confines of Buddhism in his approach to nature ${ }^{4}$. The standard Buddhist stance towards the natural environment is grounded in the conviction that the physical universe as we know is an illusion (the Sanskrit maya). Viewed from that perspective, an excessive emotional involvement in, say, the survival of whales or redwood trees is, in a way, beside the point, if not pointless. Hence, perhaps, Snyder's uneasiness with the Buddhist indifference towards the wilderness as such. Already in a 1957 entry of his "Tanker Notes" he writes: "Woke early on my cot on the boatdeck \& saw a bird flash in, soaring around the trees on shore - archaic planet epochs, bird-and-rock dawn, mountain and ocean feeling - curiously absent in Japan" (1969: 56, emphasis mine). Given the journal's central theme of spiritual quest, in which Japanese Zen-Buddhism plays a prominent part, the remark is more than just a fleeting reference to the tamed (or "cultivated" - in both senses of the word) nature of the Japanese countryside. In the context of the entire book, Japan stands, among other things, for the land of Zen-Buddhist illumination. The absence of the wilderness spirit in Japanese culture testifies to a spiritually detrimental side-effect of the Buddhist otherwordly detachment from the natural environment ${ }^{5}$. Another reason may be simply the ancient character of Far-Eastern civilizations. Unlike in China or Japan, the conquest of the wilderness in America was completed only a little over a century ago. The process often entailed a confrontation of modern economy, technology and worldview with essentially Paleolithic or Neolithic subsistence modes. What in Europe or the East amounted to a gradual social transformation, centuries in the making, was a violent conflict on the American frontier. As Snyder explains,

Much has been said about the frontier in American history, but overlooking perhaps some key points: the American confrontation with a vast wild ecology, an earthly paradise of grass, water and game - was mind-shaking. Americans lived next to vigorous primitives whom they could not help but respect and even envy, for three hundred years. [...] For Americans, "na- 
ture" means wilderness, the untamed realm of total freedom - not brutish and nasty, but beautiful and terrible. [...] "Wild" in the Far East means uncontrollable, objectionable, crude, sexually unrestrained, violent; actually ritually polluting. [...] One of the most remarkable institutions in Western thought was Rousseau's Noble Savage: the idea that perhaps civilization has something to learn from the primitive (1969: 119-120).

In other words, American culture is young enough to manifest an ongoing concern about the despoilment of the American wilderness and the devastation of Native American tribal cultures; for the Far East it may already be too late.

The critique of the Oriental-type rejection of the wilderness, both without and within, is explicit in "The Call of the Wild." Here is the poem's second section:

The ex acid-heads from the cities

Converted to Guru or Swami,

Do penance with shiny

Dopey eyes, and quit eating meat.

In the forests of North America,

The land of Coyote and Eagle,

They dream of India, of

forever blissful sexless highs.

And sleep in oil-heated

Geodesic domes, that

Were stuck like warts

In the woods.

And the Coyote singing

is shut away

for they fear

the call

of the wild.

And they sold their virgin cedar trees, the tallest trees in miles,

To a logger

Who told them,

"Trees are full of bugs."

Western neophytes indiscriminately embracing an exotic spirituality miss an important spiritual lesson taught by the receding American wilderness. This kind of irresponsiveness to the earth-oriented mysticism or, in other words, to the telluric sublime, provides an implied link with the poem's next section. There the imagery shifts from realism to surrealism, combining the oneiric and the symbolic: 
The Government finally decided

To wage the war all-out. Defeat is Un-American.

And they took to the air,

Their women beside them in bouffant hairdos putting nail-polish on the gunship cannon-buttons.

And they never came down, for they found, the ground is pro-Communist. And dirty. And the insects side with the Viet Cong.

So they bomb and they bomb

Day after day, across the planet blinding sparrows breaking the ear-drums of owls splintering trunks of cherries twining and looping deer intestines in the shaken, dusty, rocks.

All these Americans up in special cities in the sky Dumping poisons and explosives Across Asia first, And next North America,

A war against earth.

When it's done there'll be no place

A Coyote could hide.

The surrealist image of American pilots who, accompanied by their spruced-up women, bomb the enemy's territory and never return to the "dirty" earth is an emblematic rendition of the conflict between the sky-oriented and earth-oriented spiritualities. "A war against earth" is a war against the telluric spirit of the wilderness still present in some indigenous tribal cultures and symbolized in the poem by the Coyote, both the actual animal and the trickster figure in many Native American mythologies (the upper-case letter is a clear hint at the animal's symbolic status in the text).

Given the archetypal symbolic connection between a woman's body and the earth in telluric mythologies it is ironic that the pilots' women accompany their 
men on the life-destroying mission. As historians and anthropologists tell us, the Paleolithic and Neolithic religious symbols of earth-oriented spirituality were subsequently taken over and twisted by the patriarchal cultures that followed, including those of Judaism and Christianity (cf. Eisler 1988, Gimbutas 2001, Stone 1978, Turner 1990). The poem's surrealist imagery can be interpreted as a veiled reference to such a process of transforming and perverting the original meanings of archaic religious symbols. Thus the bombing mission could be a perverted version of the shamanic flight, a recurrent symbol in telluric religions, which to traditional Native Americans denoted a spiritual journey in search of a healing vision (cf. Eliade 1994). The image of the women's bouffant hairdos is another luminous detail, especially in the light of Snyder's commentary included in "Dharma Queries:" "Long hair is to accept, go through the powers of nature. Such are the Shaivite yogins; or the Kagyü-pa and Nyinma-pa lamas; the ancient Rishis" (1969: 133). Long hair has symbolic power in many tribal cultures the world over. Body-painting has also been a wide-spread practice among tribal peoples (in Europe the custom survived until the Middle Ages, for instance among Britain's Celtic warriors going to battle). One of mankind's archetypal spiritual intuitions must have been the belief in the potential sacredness of the human body ${ }^{6}$. Long hair and body-painting symbolized the ongoing connection to the cosmic order (cf. Campbell 1991). Given such anthropological contexts, the women's "bouffant hairdos" and "nail polish" are secularized parodies of ancient religious symbolizing practices. They are vivid, everyday reminders of a culture in which the human body has been desacralized. In short, the women who have joined their men on the destructive, air-borne mission have forfeited their archetypal telluric powers.

So far, the decoding of the poem's message has been somewhat predictable. Admittedly, were it not for the final strophe the entire longish lyric would read perhaps like a little too-obvious, not to say propagandist, critique of mainstream Anglo-American middle-class culture and the US foreign policy of the 1960s. What sounds brilliant in an essay may not always work in a poem and the spirit of expository prose is sometimes too obtrusively present in Snyder's verse ${ }^{7}$. The last strophe, however, labeled the "envoy," does contain the much-needed element of surprise:

I would like to say

Coyote is forever

Inside you.

But it's not true.

The surprise, of course, is in the anti-essentialist import of the envoy. The loss of the coyote will be irretrievable because the wilderness the animal represents constitutes an autonomous ontological realm the experience of which cannot be reproduced through meditation or any other mental effort on man's part. Contrary 
to what he claims, for example, in "Buddhism and the Coming Revolution" (see the quote above) about reconstructing from the unconscious the extinct elements of archaic cultures, Snyder insists, this time, that the trickster spirit of the wild will be gone with the disappearance of its emblem. This seems to go against the grain of the central conceptual metaphor of essentialist discourse, be it in its Zen-Buddhist or environmentalist variety, namely the metaphor of looking within yourself for what is also out there. In the poem, the loss of the single animal (and, by extension, the potential extinction of the entire species it represents) cannot be compensated by some heightened state of self-awareness. Consciousness raising will not do.

Such a sudden shift from essentialism to anti-essentialism could be, under different circumstances, interpreted as a turning point in a thinker's career. In Snyder's case, however, this does not seem to be the case. In the several expository books that followed Turtle Island the apparently essentialist stance returns. Consider the following excerpt from The Practice of the Wild:

Our bodies are wild. [...] The body does not require the intercession of some conscious intellect to make it breathe, to keep the heart beating. It is to a great extent self-regulating, it is a life of its own. Sensation and perception do not exactly come from the outside, and the unremitting thought and image-flow are not exactly inside. The world is our consciousness, and it surrounds us. There are more things in mind, in the imagination, than "you" can keep track of - thoughts, memories, images, angers, delights, rise unbidden. The depths of mind, the unconscious, are our inner wilderness areas, and that is where a bobcat is right now. I do not mean personal bobcats in personal psyches, but the bobcat that roams from dream to dream. The conscious agenda-planning ego occupies a very tiny territory, a little cubicle somewhere near the gate, keeping track of some of what goes in and out (and sometimes making expansionistic plots), and the rest takes care of itself. The body is, so to speak, in the mind. They are both wild. (1990: 17-18)

Very much like in "Buddhism and the Coming Revolution," and again evidently fleshing out on Jung's idea of the collective unconscious, Snyder constructs an elaborate organicist conceit in which the single self is firmly grounded in a larger whole, an organic web of interconnections and mutual dependencies of which man partakes by the same right as all the planet's living organisms. The individual's major spiritual goal in life should be arriving at a complete comprehension of this fundamental ontological fact. Snyder, this time in the more "orthodox" Buddhist and environmentalist fashion, counters the potential argument that human beings are special among mammal primates because they have language with another, similar metaphor:

Language is learned in the house and in the fields, not at school. Without having ever been taught formal grammar we utter syntactically correct sen- 
tences, one after another, for all the waking hours of the years of our life. Without conscious device we constantly reach into the vast word-hoards in the depths of the wild unconscious. We cannot as individuals or even as a species take credit for this power. (1990: 18)

Such organic imagery is typical of essentialist discourse. The question that arises, then, is why is the Coyote "not within" us in a 1969 poem but the bobcat from a 1990 essay is? Was the poet not speaking about the same "depths of mind, the unconscious" and "our inner wilderness areas" as the essayist? One way out of this apparent contradiction would be to view Snyder's ontological and epistemological concepts in the light of Neo-Aristotelian thought.

An example of Neo-Aristotelian thinking at its most lucid and immediately applicable is Martha Nussbaum's political philosophy. Central to Nussbaum's thought, and particularly relevant in the context of Snyder's "anti-essentialist essentialism," is her concept of human capability. (Thus her entire philosophy is often referred to alternately as the Human Development Approach or the Capability or Capabilities Approach. ${ }^{8}$ ) Nussbaum outlines her philosophical stance as follows:

The Capabilities Approach can be provisionally defined as an approach to comparative quality-of-life assessment and to theorizing about basic social justice. It holds that the key question to ask, when comparing societies and assessing them for their basic decency or justice, is, "What is each person able to do and to be?" In other words, the approach takes each person as an end, asking not just about the total or average well-being but about the opportunities available to each person. [...] The approach is resolutely pluralist about value: it holds that the capability achievements that are central to people are different in quality, not just in quantity; that they cannot without distortion be reduced to a single numerical scale; and that a fundamental part of understanding and producing them is understanding the specific nature of each. (2011: 18-19)

Quoting Amartya Sen, her major collaborator in the Human Development project, Nussbaum introduces some clarifying, if subtle, distinctions when it comes to human capabilities:

In other words, they [i.e. capabilities] are what Sen calls "substantial freedoms," a set of (usually interrelated) opportunities to choose and to act. In one standard formulation by Sen, "a person's 'capability' refers to the alternative combinations of functionings that are feasible for her to achieve. Capability is thus a kind of freedom: the substantive freedom to achieve alternative functioning combinations." In other words, they are not just abilities residing inside a person but also the freedoms or opportunities created by a combination of personal abilities and the political, social, and economic 
environment. To make the complexity of capabilities clear, I refer to these "substantial freedoms" as combined capabilities. [...] Of course the characteristics of a person (personality traits, intellectual and emotional capacities, states of bodily fitness and health, internalized learning, skills of perception and movement) are highly relevant to his or her "combined capabilities," but it is useful to distinguish them from combined capabilities, of which they are but a part. I call these states of the person (not fixed, but fluid and dynamic) internal capabilities. They are to be distinguished from innate equipment: they are trained or developed traits and abilities, developed, in most cases, in interaction with the social, economic, familial, and political environment. [...] One job of a society that wants to promote the most important human capabilities is to support the development of internal capabilities - through education, resources to enhance physical and emotional health, support for family care and love, a system of education, and much more. (Nussbaum 2011: 20-21)

The applicability of Nussbaum's Capabilities Approach to Snyder's essentialism becomes more apparent at this point. The Coyote - which is not inside us - is simply not part of our "innate equipment." In other words, we are not - unlike, it seems, most other mammals - born with a natural, immediate sense of rapport with the wilderness. (This is so on condition, of course, that those mammals are born in their natural habitat - like, say, zebras on the savannah. It is doubtful whether zoo-born zebras would possess the same "natural" qualities and aptitudes as those born in the wild.) The intuitive emotional rapport with the wilderness is, potentially, one of our internal capabilities. It can only be "trained or developed" in interaction with the wilderness (at this point one would have to add the adjective "natural" to Nussbaum's list of qualifiers accompanying the word "environment"). Without the compelling presence of a wilderness out there, a human being is deprived of an opportunity to develop a crucial internal capability, which, in turn, impairs or impoverishes his/her set of combined capabilities. It follows that one of the tasks of a decent society would be to preserve the wilderness for the future generations as, in Nussbaum's view, it is primarily the society's or the government's responsibility to secure living conditions conducive to the cultivation of combined capabilities and, as a result, to "a life worthy of human dignity" (Nussbaum 2011: 32). The philosopher writes:

Why is it important to distinguish internal capabilities from combined capabilities? The distinction corresponds to two overlapping but distinct tasks of the decent society. A society might do quite well at producing internal capabilities but might cut off the avenues through which people actually have the opportunity to function in accordance with those capabilities. Many societies educate people so that they are capable of free speech on political matters - internally - but then deny them free expression in practice through repression of speech. [...] Because combined capabilities are defined as in- 
ternal capabilities plus the social/political/economic conditions in which functioning can actually be chosen, it is not possible conceptually to think of a society producing combined capabilities without producing internal capabilities. We could, however, imagine a society that does well in creating contexts for choice in many areas but does not educate its citizens or nourish the development of their powers of mind. (2011: 21-22)

A variant of the latter scenario, though couched in different terms, is presented in Terry Eagleton's 2003 book After Theory. The interesting thing about the British critic's approach is that he seems to have it both ways; resolutely essentialist in his adherence to the concept of human nature as such, Eagleton somehow manages to avoid the staple political dangers of essentialism (and remain a Marxist to boot). That is because to Eagleton, like to Aristotle, human nature is not a static biological given, but rather a mental predisposition that manifests itself in a specific existential project. Thus it is more of a task, or challenge, than a set of characteristics. Eagleton cites an anecdote about George Best - "perhaps the finest footballer in history until alcoholism brought him low" (Eagleton 2003: 113) - to illustrate his point:

Best the ex-footballer was lounging in a five-star hotel room surrounded by caviar and champagne, with a former Miss World lounging amorously beside him, when a member of the hotel staff entered, weighed down with yet more luxury goods. Gazing down at the supine star, he shook his head sadly and murmured: "George, where did it all go wrong?" (2003: 113)

Despite all the conventional trappings of macho success, of having made it in the world, "there is something in our intuition", Eagleton tells us (2003: 113) that George Best was not at his best at that moment.

The joke, of course, is that one would hardly claim that life had gone wrong for a man with such a lavish lifestyle. This is how Best tells the story himself. Yet the hotel worker was right: Best's life had gone wrong. He was not doing what it was in him to do. He was certainly enjoying himself, and might even in some sense have been happy; but he was not flourishing. He had failed at what he was supremely equipped to excel at. It is true that his life was probably more pleasurable than it had been in his footballing days, when he was constrained to break off nightclubbing from time to time in order to train. It is not that he had been happier as a footballer in the sense of enjoying himself more, though he managed to enjoy himself enough for a whole league of players even then. [...] It is rather that he had ceased to prosper. (Eagleton 2003:113-114)

Interestingly, the organicist metaphors are as revealing as they are deceptive. The ex-footballer failed to do what it was in him to do. This spatial metaphor would 
apparently imply that at one point in his life he lost touch with the "bobcat" inside him, with his "inner wilderness areas" (to quote Snyder again). That is why he was not "flourishing," much like a plant transplanted into a soil that does not agree with its inner constitution. The conceptual metaphor of flourishing recurs in the writings of Neo-Aristotelians. That is why, perhaps, Nussbaum eventually introduces yet another type of capability - the "basic" one - both to acknowledge the pervasiveness of such organicist metaphors in the philosophical discourse she belongs in and to make sure that humans' inborn capacities are not viewed as synonymous with internal capabilities:

Internal capabilities are not innate equipment. The idea of innate equipment does, however, play a role in the Human Development Approach. After all, the term "human development" suggests the unfolding of powers that human beings bring into the world. Historically, the approach is influenced by philosophical views that focus on human flourishing or self-realization, from Aristotle to John Stuart Mill in the West and Rabindranath Tagore in India. And the approach in many ways uses the intuitive idea of waste and starvation to indicate what is wrong with a society that thwarts the development of capabilities. Adam Smith wrote that deprivation of education made people "mutilated and deformed in a[n] ... essential part of the character of human nature." This captures an important intuitive idea behind the capabilities project. We therefore need a way to talk about these innate powers that are either nurtured or not nurtured, and for that we may use the term basic capabilities. (Nussbaum 2011: 23)

It is at this point that one should extend the organicist metaphor so as not to fall into the trap of simplistic, biological essentialism. In other words, the whole project of human flourishing, as discussed by both Nussbaum and Eagleton, is not about discovering what kind of "plant" humans are, but what kind of "plant" you are.

There is no need to imagine, as many anti-essentialists do, that natures need be eternally fixed. The most dramatic example we have of nature which is perpetually re-making itself is human nature. The champions of transgression are right at least to this extent, that it is in our nature to go beyond ourselves. Because we are the kind of labouring, linguistic, sexual, sociable animals we are, it is in our nature to give birth to culture, which is always changeable, diverse and open-ended. So it is easy to mistake the peculiar kind of nature we have for no nature at all, and come like the champions of transgression to cultivate a Faustian image of ourselves. (Eagleton 2003: 119)

Such ideas resonate powerfully with Snyder's concept of ever-changing human nature. They also bring to mind G.E.M. Anscombe's witty refutation of the commonly-accepted spatial metaphor of the human soul as something immaterial which resides "inside" us. If human souls were immaterial beings, Anscombe ar- 
gues, then they could not be individuated in the way that we usually imagine them to be - that is as subsistent immaterial thinking entities both generic and unique to the individual people "carrying" them. After all,

It is spatiality with its spread-out-ness that makes it possible to have many things all of one kind, like a sheet of postage stamps all the same. But if something has no dimensive quantity to it, if its essence does not involve any matter but it is a pure form, then there can only be one of it - just as Plato called his forms monads: there could only be one form of each kind of thing. (Anscombe 2005: 17)

Anscombe does not dismiss the very notion of the individual soul as such. Instead, she offers a new metaphor - one that is, admittedly, harder to grasp because it is not spatial: "There is a primary principle of the life of any kind of material living thing. I mean: a primary principle of dandelion life in a dandelion, of lion life in a lion. This primary principle I call its soul" (Anscombe 2005: 18). It is hard to visualize a "principle," primary or not. That is why, probably, Anscombe illustrates her meaning with the familiar image of germinating seeds. Suppose, she says, you saw two identical-looking seeds and wanted to know if they were really of the same kind. The best test, of course, would be to plant them and wait to see what kind of plants they will grow into. Likewise, we intuitively know that manufacturing an artificial seed that looks exactly the same like the natural model is no guarantee that it will produce a plant of the same kind. There is more to generic identity than mere appearance.

Knowing the kind, you know from what it came and what, if anything, it will naturally grow into. Knowledge of the kind determines that further knowledge so long as in knowing the kind you know that it is a seed and the seed of such a tree. This is because the kind determines what plant this seed will become if it grows. The notion of the kind includes that of a determinative principle or form according to which the life develops and proceeds. Thus the single-celled creature splits into two structural replicas of itself, and the many-celled plants and animals have cell differentiation and organization of many differentiated tissues into a whole of a certain pattern. Knowledge of the pattern proper to the kind is implicit in the doctor's and geneticist's concept of a 'syndrome'. You don't call it a syndrome that a baby learns to stand up and walk, holds its head up, looks about it and goes towards objects which it then clutches. A syndrome is a set of phenomena that are not according to the pattern proper to the kind but are damaging to it. (Anscombe 2005: 19-20, emphasis mine)

Anscombe admits that, "It may sound odd, because unusual, to speak of the soul of a daffodil. But a daffodil plant is certainly not inanimate, and so must have such a primary principle, its determinative form, as the principle of its being 
a living daffodil" (2005: 20). There are obvious problems with a human soul construed along such lines. While in the case of daffodils or lions behavioral patterns "proper to the kind" are fairly easy to locate and describe, things get more complicated when it comes to humans. It is revealing that Anscombe's example of such a pattern for humans is restricted to the "normal" behavior of a healthy toddler. This is, indeed, as far as such patterns can take us, circumscribed as they are to the realm of physiological functions. However, while in the case of plants or animals such functions are apparently all there is to study if one wants to get to know the "soul" of a flower or a wild cat, they obviously do not exhaust the range of human actions and responses. So, the "primary principle" of human life in a human being is far more elusive.

One cannot overemphasize this "because the concept of nature is often linked to the idea of function" (Eagleton 2003: 119-120). Eagleton writes:

What are human beings for? The answer is surely: nothing - but this, precisely, is the point. Our function is to be functionless. It is to realize our nature as an end in itself. We need the word "nature" here to avoid having to say "realize ourselves as an end in itself," since a good deal of what we are capable of should by no means see the light of day. So "nature" here means something like "the way we are most likely to flourish." And since what this involves is by no means obvious, this is another reason why it is easy to mistake this situation for not having a nature at all. (2003: 120)

It follows that the existence of human nature does not presuppose any particular teleological project for mankind or a specific purpose human beings have been created for. Flourishing, according to Aristotle, Eagleton, Nussbaum and Anscombe, means excelling at being fully human or making the most of one's humanity, but not in any normative, prescribed, generic sense. Well aware of that, Anscombe eventually does not limit her definition of the human soul to the idea of a pattern proper to humankind or a determinative pattern or form according to which human life develops and proceeds. Unlike with daffodils or lions, "the intellective principle is the differentia of the human soul" (Anscombe 2005: 22). A major manifestation of this principle, according to Anscombe, is language with its power to generate abstract concepts. Anscombe's argument is representative of the kind of "essentialism" that most Neo-Aristotelians espouse - it starts with an apparent organicist or biological closure (with humans being compared to plants and animals) only to end up with an open-ended conclusion. (After all, if what makes us human is our language then the list of potentially human behavings is virtually inexhaustible.)

Eagleton points out to a number of philosophical traditions, including those of Judaism, Christianity, and Marxism, that support this kind of quasi-essentialism:

Aristotle thought that there was a particular way of living which allowed us, so to speak, to be at our best for the kind of creatures we are. This was 
the life conducted according to the virtues. The Judaeo-Christian tradition considers that it is the life of charity or love. What this means, roughly speaking, is that we become the occasion for each other's self-realization. It is only through being the means of your self-fulfilment that I can attain my own, and vice versa. There is little about such reciprocity in Aristotle himself. The political form of this ethic is known as socialism, for which, as Marx comments, the free development of each is the condition for the free development of all. It is, as it were, politicized love, or reciprocity all round. (2003: 122)

It is at this point that Eagleton and Snyder pass company as fellow Neo-Aristotelians. To the British critic socialism is the answer, allegedly providing the optimal conditions for a harmonious blend of one's private and public self. To Snyder, it seems, state-supported socialism would mean but another oppressive political system, very much in the mentally-restrictive tradition of what he calls "the Judaeo-Capitalist-Christian-Marxist West." To complicate things further, Snyder's insistence that the revolution must be carried out on the exclusively personal plane, if it is not to degenerate into yet another form of social oppression, resonates with the ideas of resolutely anti-essentialist Richard Rorty, who writes:

There is no way in which philosophy, or any other theoretical discipline, will ever let us do that [i.e. combine in a single political project individual self-realization and social justice]. The closest we will come to joining these two quests is to see the aim of a just and free society as letting its citizens be as privatistic, "irrationalist," and aestheticist as they please as long as they do it in their own time - causing no harm to others and using no resources needed by those less advantaged. There are practical measures to be taken to accomplish this practical goal. But there is no way to bring self-creation together with justice at the level of theory. The vocabulary of self-creation is necessarily private, unshared, unsuited to argument. The vocabulary of justice is necessarily public and shared, a medium for argumentative exchange. (Rorty 1989: xiv)

Here, the major point of divergence between Eagleton and Nussbaum on one hand and Rorty on the other is the epistemological status of personal self-realization. The bone of contention, in other words, is whether one's thriving or flourishing as a human being is a matter of objective assessment or if it is exclusively a matter of one's purely subjective, idiosyncratic and thus arbitrary choice. Eagleton, following Aristotle, argues that "flourishing cannot really be a subjective affair" (2003: 126). Admittedly,

Some kinds of happiness may be subjective, in the sense that people are often contented if they think they are. Sometimes you just have to take their word for it. You may be wrong about thinking you are happy in some deeper 
sense of the word, but it is hard to see how you can be wrong about feeling gratified or at ease, any more than you can have a pain and not know about it.

The kind of happiness that matters, however, is the kind which is much less easy to determine. You cannot tell whether your life is flourishing simply by introspection, because it is a matter of how you are doing, not just of how you are feeling. Happiness is about living and acting well, not just about feeling good. For Aristotle, it is a practice or activity rather than a state of mind. It is about realizing your capacities, not having a particular outlook on life. (Eagleton 2003: 127)

Introducing the distinction between "subjective" happiness, which amounts to "feeling gratified or at ease," and the "kind of happiness that matters," which is "about living and acting well," enables Eagleton to claim that contented people need not be objectively happy. Thus the contentment, say, of a woman willingly choosing a polygynous marriage can be explained by her ignorance of her specifically human potential (i.e. her human nature). It is so, because "you have to have some idea of what counts as a specifically human kind of prospering. It is not just an individual affair" (Eagleton 2003: 127). It follows from such a radically objectivist stance that some people ought to be re-educated. The Marxist Neo-Aristotelian writes:

Ethics is in Aristotle's view the science of human desire, since desire is the motive behind all our actions. The task of an ethical education is to reeducate our desires, so that we reap pleasure from doing good acts and pain from doing bad ones. [...] You can, then, be mistaken about whether you are flourishing, and someone else may be more wisely perceptive about the matter than you yourself. This is one important sense in which morality is objective. (Eagleton 2003: 129)

What remains to be established is the objective criteria of whether one is thriving as a human being or not. Where are we to look for clues, if we should not trust the inner voice of our whims? The "public criteria," in Eagleton's phrase, are out there:

I cannot see that I am doing well just by looking into my soul. As Ludwig Wittgenstein remarked, the best image of the soul is the human body. The best image of what I am is how I am behaving. The two are as closely bound up with each other as a word and its meaning. These public criteria provide us with a case against those for whom happiness or well-being is not a practical condition but an individual state of mind. But happiness is not just a state of mind, any more than playing chess is just a state of mind. People may feel content with their situation; but if they are not, for example, allowed to play an active role in determining their own lives, then in Aris- 
totle's eyes they cannot be genuinely fulfilled. Virtue for Aristotle is a kind of excellence; and though slaves may feel in good shape from time to time, they are not exactly object-lessons in how to excel at being human. (Eagleton 2003: 130-131)

Given this emphasis on the objective criteria of one's thriving as a human being and their close connection to the bodily sphere, Snyder's revaluation of the word "primitive" in the context of tribal cultures is clearly Neo-Aristotelian:

Having fewer tools, no concern with history, a living oral tradition rather than an accumulated library, no overriding social goals, and considerable freedom of sexual and inner life, such people live vastly in the present. Their daily reality is a fabric of friends and family, the field of feeling and energy that one's own body is, the earth they stand on and the wind that wraps around it; and various areas of consciousness.

At this point some might be tempted to say that the primitive's real life is no different from anybody else's. I think this is not so. To live in the "mythological present" in close relation to nature and in basic but disciplined body/ mind states suggests a wider-ranging imagination and a closer subjective knowledge of one's own physical properties than is usually available to men living (as they themselves describe it) impotently and inadequately in "history" - their mind-content programmed, and their caressing of nature complicated by the extensions and abstractions which elaborate tools are. A hand pushing a button may wield great power, but that hand will never learn what a hand can do. Unused capacities go sour. (Snyder 1969: 117-118)

A consummate stylist, Snyder sure knows how to hit the sensitive spots in the reader's portion of the collective unconscious. Firstly, the memorable alliterations ("a fabric of friends and family, the field of feeling") employed to describe the emotionally crucial issues (friends, family, feelings, one's own body) create a sense of an organic bond between the Noble Savage's private and public self, body and mind, thoughts and actions, a cosmic connection hidden to the uninitiated but rediscovered by the writer. The underlying metaphor here is, of course, that of harmonious, all-inclusive wholeness. Secondly, the subtle eroticization of imagery makes the critique of Western civilization all the more poignant, personal and emotively persuasive. (Incidentally, the erotic undertones of "living impotently" in history rather than in the present moment and of the unnecessarily mediated "caressing" of nature seem particularly addressed to the male reader's both subconscious and unconscious mind - in Freudian and Jungian terms, respectively.)

This brings us to the major stylistic forte of the passage, that is the cumulative consistency of its imagery. The first paragraph establishes the central metaphorthat of freedom within and without which results in a more intense and therefore authentic spiritual life; the lack of mental barriers between the tribal individual 
and his/her immediate environment liberates the mind, opening it to the riches of one's inner life. The landscape becomes the mindscape, as it were, generating a mental feedback effect. One's own body becomes thus a "field" of energy, ruled by the same cosmic laws as the outer world. The natural order is viewed as intrinsically benign and life-friendly. That is why the wind "wraps around" the earth rather than, say, blowing or sweeping over its surface. The concept of inner freedom is consistently expressed through a number of spatial metaphors, all of them having to do, in one way or another, with intimate, unmediated contact with one's inner and outer reality, facilitated by the lack of mental barriers, constraints, or limitations (cf. "live vastly in the present," "field of feeling and energy," "areas of consciousness," "a wider-ranging imagination").

In other words, it is "natural" for us to be spiritual, provided that we "naturally" (i.e. unselfconsciously) cultivate a close bond with the natural environment. Snyder writes:

[Alvar] Núñez was the first European to encounter North America and its native myth-mind, and Ishi was the last Native American to fully know that mind - and he had to leave it behind. What lies between those two brackets is not dead and gone. It is perennially within us, dormant as a hard-shelled seed, awaiting the fire or flood that awakes it again. (1990: 14, emphasis added)

The metaphor of a germinating seed recurs in Snyder's texts, related as it is to the fundamental concept of his environmentalist prose, namely that wild nature constitutes a climactic stage in the process of ecosystemic evolution. In a talk at Brown University Snyder declared:

The communities of creatures in forests, ponds, oceans, or grasslands seem to tend toward a condition called climax, "virgin forest" - many species, old bones, lots of rotten leaves, complex energy pathways, woodpeckers living in snags, and conies harvesting tiny piles of grass. This condition has considerable stability and holds much energy in its web - energy that in simpler systems (a field of weeds just after a bulldozer) is lost back into the sky or down the drain. All of evolution may have been as much shaped by this pull toward climax as it has by simple competition between individuals or species. (1980: 173)

If left alone, then, nature tends to create a state of climactic complexity which remains unparalleled in its ontological intensity; no human endeavor, however technologically sophisticated, can top that. To be able to do this, though, nature must - to repeat - be left alone by human beings. Nature at its wildest, most pristine state is nature at its best.

To clarify this point Snyder posits a subtle but important distinction between nature and the wilderness. To the author of The Practice of the Wild nature is syn- 
onymous with "the physical universe and all its properties" (1990: 9). As Snyder puts it, "Science and some sorts of mysticism rightly propose that everything is natural. By these lights there is nothing unnatural about New York City, or toxic wastes, or atomic energy, and nothing - by definition - that we do or experience in life is "unnatural"' (1990: 9).

The wild category, in turn, includes everything that grows (both in the literal and metaphorical sense) by and of itself. Thus one can speak not only of wild nature or wild animals, but also of wild individuals, societies, or behavior. Wild societies, for example, are those "whose order has grown from within and is maintained by the force of consensus and custom rather than explicit legislation" (Snyder 1990: 10).

So we can say that New York City and Tokyo are "natural" but not "wild." They do not deviate from the laws of nature, but they are habitat so exclusive in the matter of who and what they give shelter to, and so intolerant of other creatures, as to be truly odd. Wilderness is a place where the wild potential is fully expressed, a diversity of living and nonliving beings flourishing according to their own sorts of order. In ecology we speak of "wild systems." When an ecosystem is fully functioning, all the members are present at the assembly. To speak of wilderness is to speak of wholeness (Snyder 1990: 12).

Both Snyder and Neo-Aristotelian philosophers speak of "flourishing" when referring to the best possible mode of being in this world for humans. Eagleton's argument that George Best may have prospered but did not flourish after he had stopped playing football sounds almost like an illustration of Snyder's point. Best simply did not flourish according to his own (i.e. human) sort of order. A good life, in other words, is about living in as intense or climactic way as possible. In a similar vein, Nussbaum argues that increasing the scope and range of one's personal capabilities is intrinsically conducive to a life worthy of human dignity. The underlying conceptual metaphor here is that of arriving at some sort of climactic experience of one's humanity. This resonates with Snyder's view that nature is not "good" simply because it is perfectly "natural," but because it provides a compelling example of the most sophisticated, most intensified mode of being - only in this sense is being natural "good for us," in all the senses of the phrase.

In sum, human beings inhabiting a world without coyotes would be like George Best inhabiting a world without football fields. Speculating about the potential footballer in George Best's nature presupposes the existence of football. In a society where football does not exist such speculations would be pointless. Similarly, the very idea of wildness presupposes the existence of the wilderness. Wild nature is thus both the generator and the best possible embodiment of the otherwise inconceivable idea. Without wild nature's example out there humans would not have been able to come up with the concept of being "natural" within. In this sense the Coyote is not intrinsically within us, it is only potentially there 
and it takes a real coyote to make us aware of that. John Elder must have had something similar in mind when he wrote in the mid-1980s that poetry

... is in ecological terms the edge between mankind and nonhuman nature, providing an access for culture into a world beyond its preconceptions. A similar sense of poetry's mediating role informs Robinson Jeffers's attempt at a vision of "inhumanism." Jeffers's hope was to locate his poems beyond the narrow circle of human understanding, to speak past his own humanity. Expansive subject matter serves a similar function in the poetry of Snyder and Ammons; though their voices remain personally self-conscious, revelations of nature's intricacy burst continuously through the frameworks of their understanding, as well as through conventional Western attitudes. Rather than domesticating nature, the poets are themselves assimilated into its ever-emerging and overwhelming particularity. The richness of natural process shatters human expectations, recentering mental circles and broadening their necessary circumference. (Elder 1996: 210)

In short, nature - or, in Snyder's terms, Wilderness - remains our ultimate point of reference when it comes to being natural.

\section{Notes}

1 Myths and Texts is a classic instance of such an implicitly ecological book. The extensive cultural quotations from Native American myths signal the poet's spiritual affinities with tribal animism and its holistic approach to the wilderness. Not surprisingly, Snyder's book was lauded by one critic as "an imaginative application of anthropological materials" (Steuding 1976: 66).

2 Essentialism is hereby understood as an epistemological tradition in philosophy which presupposes the existence of generic human nature, one that each human being is born with, regardless of his/her subsequent socio-cultural conditioning. Anti-essentialism, by contrast, holds that we are not "born" but "made" human by extensive socialization.

3 It remains an open question to what extent the fact that the phrase "what is to be done" could be a direct quote from Lenin should affect our interpretation of the poem. It seems, though, that, given Snyder's otherwise explicit emotional detachment from Marxism (which he expressed on a number of occasions), one should not read too much into the quote. Unlike so many left-wing intellectuals in America, Snyder is not dismissive of the all-too-real historical experience of political oppression under Marxist regimes.

As Thomas J. Lyon has put it, "Tingeing the Zen core with irony [...] is one of Snyder's singular contributions to modern poetry, a byproduct of the connection he has knitted in his life between East and West. In a sense, Snyder is moving westward in the way that Whitman meant for us to do, the total effect of his final synthesis being, to use one of his essay titles, a 'Passage to More Than India'" (Lyon 1991: 38). experienced by many contemporary American nature poets. Consider, for example, Robinson Jeffers explaining the difference between what he calls "Oriental" pantheism and that of his own: "It is the feeling ... I will say the certitude ... that the world, the universe is one being, a single organism, one great life that includes all life and all things; and is so beautiful that it 
must be loved and reverenced; and in moments of mystical vision we identify ourselves with it. This is, in a way, the exact opposite of Oriental pantheism. The Hindu mystic finds God in his own soul, and all the outer world is illusion. To this other way of feeling, the outer world is real and divine; one's own soul might be called an illusion, it is so slight and so transitory" (1956: 12).

6 Sacredness is here understood in standard anthropological terms, that is as a manifestation of supernatural powers revelatory of a link with the cosmic order. It is thus more or less synonymous with the concept of hierophany as espoused by Mircea Eliade (cf. 1994: 8-10). Incidentally, Snyder seems sometimes too reliant on the spiritual profundity of his poems' message which, he evidently believes, will take care of its own form. The criticism one could - as at least one New Critic did - direct against William Carlos Williams's celebrated "The Red Wheelbarrow" is, arguably, applicable to many poems by Snyder. Robert Bly in his collection of essays American Poetry: Wildness and Domesticity argues that far too many contemporary American poets have, in one way or another, embraced the early modernists' idea of objectifying the individual perspective by means of direct, emotionally unmediated references to one's immediate physical environment. The result, in Bly's view, has been all-too-often a suppression of the poet's unrestrained associative powers. Commenting on Charles Olson's programmatic essay on "Projective Verse," Bly writes: "In demanding that the poet get rid of himself as a subjective person Olson is simply restating Eliot's belief in the desirability of 'extinguishing the personality.' To Olson the poet's inwardness is 'lyrical interference.' Some Zen teachers use language like this, but their meaning is exactly the opposite. The aim of Zen, as of a poet like Rilke, is to make men more and more inward until they stop admiring objects, at which point they will be able to see them clearly, if they wish to (1991: 13-14)".

8 Nussbaum herself, though, does make a subtle distinction here: "I prefer the term 'Capabilities Approach,' at least in many contexts, to the term 'Human Development Approach,' because I am concerned with the capabilities of nonhuman animals as well as human beings" (2011: $18)$.

\section{References}

Anscombe, G.E.M. (2005) Human Life, Action and Ethics. Exeter: Imprint Academic.

Bate, Jonathan (2000) The Song of the Earth. London: Picador.

Bly, Robert (1991) American Poetry: Wildness and Domesticity. New York: HarperPerennial.

Campbell, Joseph (1991) The Masks of God: Oriental Mythology. New York: Arkana.

Eagleton, Terry (2003) After Theory. New York: Basic Books.

Eisler, Riane (1988) The Chalice and the Blade: Our History, Our Future. San Francisco: Harper $\&$ Row.

Elder, John (1996) Imagining the Earth: Poetry and the Vision of Nature. Athens and London The University of Georgia Press.

Eliade, Mircea (1994) Szamanizm i archaiczne techniki ekstazy. Warszawa: Wydawnictwo Naukowe PWN.

Gimbutas, Marija (2001) The Language of the Goddess. London: Thames \& Hudson.

Jeffers, Robinson (1956) Themes in My Poems. San Francisco: The Book Club of California.

Lyon, Thomas J. (1991) “The Ecological Vision of Gary Snyder.” In: Murphy, P.D. (ed.) Critical Essays on Gary Snyder. Boston: G.K. Hall \& Co. 35-48.

Nussbaum, Martha C. (2011) Creating Capabilities: The Human Development Approach. Cambridge, Massachusetts and London, England: The Belknap Press of Harvard University Press.

Rorty, Richard (1989) Irony, Contingency, and Solidarity. Cambridge: Cambridge University Press. Snyder, Gary (1960) Myths \& Texts. New York: New Directions. 
Snyder, Gary (1969) Earth House Hold. New York: New Directions.

Snyder, Gary (1974) Turtle Island. New York: New Directions.

Snyder, Gary (1980) The Real Work: Interviews and Talks, 1964 - 1979, edited by Scott McLean.

New York: New Directions.

Snyder, Gary (1990) The Practice of the Wild. San Francisco: North Point Press.

Steuding, Bob (1976) Gary Snyder. Boston: Twayne Publishers.

Stone, Merlin (1978) When God Was a Woman. San Diego and New York: Harcourt Brace.

Turner, Frederick (1990) Beyond Geography: The Western Spirit Against the Wilderness. New Brunswick and London: Rutgers University Press.

Piotr ZAZULA is poet, translator, and literary scholar, who obtained his Ph.D. in American literature from the University of Wroclaw in 1997. He is the author of two poetry volumes in Polish (Sonet dla zakonnicy, 1997, and Lista cudów, 2000) and numerous academic articles in English (published in Poland, Czech Republic, Germany and Austria). In the years 1993-94 he was a Fulbright Visiting Scholar at the University of New Mexico in Albuquerque, where he did postgraduate research on contemporary Native American literature and local tribal cultures. His academic interests include modern American poetry (especially ecopoetry), Gnostic spirituality, political philosophy, and the ethnic cultures of the American Southwest.

Address: Dr. Piotr Zazula, ul. Czajkowskiego 65/2, 51-171 Wroclaw, Poland. [email: piotr.zazula@ op.pl] 
